\title{
Vocational Student's Strategies in Posing Mathematical Problems Assisted with Google Forms
}

\author{
Ririn Diyannita Sasanti*, Tatag Yuli Eko Siswono, Manuharawati \\ Mathematics Department, Universitas Negeri Surabaya, Ketintang, Surabaya 60231, East Java, Indonesia \\ ririnsasanti@mhs.unesa.ac.id
}

\begin{abstract}
The purpose of this study was to determine the ability of the student's problem in completing the task of mathematics with sub-topic translation and reflection by using the help of google form. This research method was qualitative descriptive by involving 32 students of class XI TEi2 in SMK Negeri 1 Jetis Mojokerto. The data collection was done by giving the task of filing problems and interviews. The task is given filing a problem using the help of google form. Student strategies in problem-solving included reformulation, reconstruction and imitation. The interview was done by selecting 2 respondents who could propose an imitation strategy. This happened because the proposed imitation problem was the most difficult. The analysis was used is the qualitative analysis done which through data reduction, data presentation and conclusion. The result of problem posing's task was known that the students who used reconstruction strategy equal to $74,219 \%$, imitation strategy equal to $3,125 \%$, and reform strategy equal to $3,125 \%$ and do not use strategy equal to $19,531 \%$ in making the strategy of problem.
\end{abstract}

Keywords-Problem Posing; Google Form; Vocational Student.

\section{INTRODUCTION}

Nowadays, posing problem is one of the most important activity that is discussed, especially in mathematics learning. This was because in the process of problem posing was more centered on students rather than the teacher. Teachers are more viewed as facilitators. Problem posing is one of the most widely applied methods in mathematics learning, in line with the mathematical objectives that mathematical learning directs and enables students to solve mathematical problems well in accordance with ability, creativity and could correlate mathematics with everyday life. Several studies had shown that the problem solving could develop students' mathematical ability, such as problem-solving ability and students' creative ability.

According to research conducted by [1] showed that the experimental group was given treatment of learning which the average score for solving mathematical problems increased significantly when compared to the control group that without any treatment. In addition, the overall level of problem-solving in the experimental group increased significantly between before and after treatment.

In mathematics lessons, problem-solving had diverse meanings [4] First, the problem was the formulation of a simple matter or a re-formulation of the existing problem with some changes to make it simpler and understandable in order to solve complex problems. Second, problem posing is the formulation of a matter relating to the terms of the requirements on the completed matter in order to seek other alternative solutions [5]. Third, the problem posing is the formulation of questions from the information or situation that is available, either before, during, or after the settlement of a matter [5]. Meanwhile, according to [6] posing problem has a meaning as making a problem. Based on those definitions, can be interpreted that the problem posing is to make a new problem based on information that has been given. Problem posing is closely related to problem-solving. This happened because the problem-posing which created by students can improve student problem-solving skills. With the task of problem posing, given to the student, it will be able to train the students to more creative in looking for alternative problem solving and have the better understanding of mathematical concepts.

The process of learning mathematics on vocational students slightly different when compared with high school students. Characteristics of vocational students were less active in learning mathematics, less responsive, less interest on conventional and monotonous learning. This happened the orientation of vocational students were to work after graduating from school. So, it looks like a strategy that was more interesting, challenging and fun. So, the approach of learning was done through problem posing. Selecting problem posing tasks is expected that the students would be more actively involved, build concepts based on various information received the link and implement in daily life. The plot of problem posing which in this research were 1) Teacher gave information about learning mathematics with topic of translation and reflection 2)Teacher made google form with the topic of translation and reflection 3) Students were given the task of making a problem (problem posing) and uploading on google form 4) Teacher downloaded the submission of problems that had been made by the students 5)Results of problem posing created by students are distributed to other students (not students of problem maker) to work on the problem 6) After the question was done by the students, the results were given to students made the problem to be corrected and assessed 7) The last step, the teacher evaluated and assessed. The process of the student's problem-posing task. The Google form was used due to it was cheaper, easier, free and unpaid, and also could spread the questionnaire to many respondents at the same time and all students can access through android owned. Google Form was one application in a form template or worksheet that can be used independently or together for the purpose of obtaining user information. This application works within Google Drive alongside with other applications like Google Sheet, Google Docs, and etc. This template was very easy to understand and use, and available in 
many languages options. The requirement to use it only had a Google account only for processors or form creators.

There are three problem-posing strategy according to [8] such as reformulation, reconstruction, and imitation. Reformulation was a strategy explains when problem-making was done by students by recasting elements within the original problem structure. In other words, the problem posed by the student is identical to the given problem, only different in its appearance or composition of the sentence. In this strategy, it can be used to pose or create a problem by reconstructing the known information, adding information that does not change the problem, such as brackets, replacing mathematical operations with equivalent forms on the initial problem, or combining them. Problem reconstruction was a problem-posing strategy which generated the problem by modifying the initial problem and modified it by changing the nature of the problem. Thus, the proposed problem-related in some way to the given problem posing, but the content was different. From those explanations, it could be understood that the problem-posing strategy is called reconstruction if the outcome of the problem requested problem was obtained by modifying the initial problem and modified it by changing the nature of the problem. Thus, problem posing was related and had the same intention, but it had different content. Imitation problem was a problemposing strategy referred to as imitation if the problem posed was added with the problem structure and previously problems which encountered in the next problem-solving. In the next explanation, the problem which expanded by altering new goals or relating them to other materials were included in this strategy

The purpose of this study was to determine the ability of the student's problem posing in the solving mathematics tasks with the subtopic of reflection by using the google form.

\section{METHODS}

This type of research was qualitative [7]. This research was conducted in the even semester of the academic year 20172018. The subjects of this study were 32 students of class XI TEI 2 consisted of 25 boys and 7 girls with the same average abilities which weird overall viewed the problem-posing strategy of each student. While the interview was done by taking 2 students who had an imitation strategy and asking those two students about the reasons their answers.

Data collection method which used in this research was written test. The instrument used the form of a question that uploaded in google form which consisted of four questions. Stages of this research were (1) Teacher provided information about mathematics learning with the topic of transformation and reflection,(2)Teacher made google form with the topic of translation and reflection,(3) Students are given the task to make problem (problem posing) as much as four problems and upload on google form which have been provided by teacher, (4) Teacher downloaded the submission of problems that had been made by the students, (5) Results of problem posing made by students were distributed to other students (not included students of problem-makers) to work on the problem, (6) After the question is done by the students then the result is given to the student making the problem to be corrected and assessed and, (7) Teacher evaluated and assessed the process of the task of filing the problem made by the students. Assessment or evaluation was done by categorizing students answers into three categories which were: reformulation, reconstruction and imitation. The assessment of reformulation categories was done by assessing the problems posing made by students which had the same or identical to the problems given by the teacher. It only had different the appearance or composition of the sentence. The assessment of the reconstruction category could be done outcome of problem posing was obtained by modifying the initial problem and changing the nature of the problem so that the problem content was differed depending on the student's understanding. The assessment of the imitation category could be done if the proposed problem was raised by adding from the structure of the problem and the previous problem which encountered in the next problem solving. While interviews were conducted to students who could pose problems with imitation strategies. It aimed to get information about the reasons why students choose the strategy of problem posing with imitation. This was done to explore the information of the students' submission strategies to solve problem. In the evaluation, in order to assess the strategies which used by the students, in calculation when student made a problem with a maximum of four problems which multiplied by the number of students ( 4 questions x 32 students $=128$ ). Based on the maximum number of questions, it would be assessed and categorized by Stoyanov strategy (reformulation, reconstruction, and imitation).

The presentation of data was activity in a neat and organized by presenting all data systematically. Data presentation involved determining the strategies which used by students, and described how students use the strategy. The conclusion was the final step in the interview analysis. At this stage, the conclusion was made, to described the strategy of problem posing selected by students. The task of problem posing which uploaded in google form:

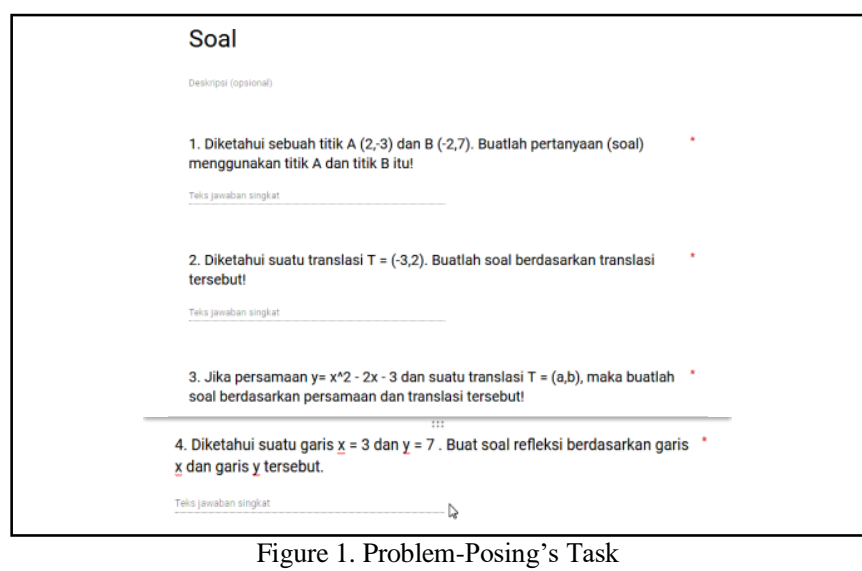

\section{RESULTS AND DISCUSSION}

In this research, it, generated description about the process of problem posing with assisted google form made by the student of XI TEI2. Students of XI TEI 2 were 32 students consisted of 25 boys and 7 girls students. Age's range of students was around 16-17 years old. 
TABLE I: NUMBERS OF PROBLEMS ARE MADE BY STUDENTS IN THE PROBLEM-POSING TASK

\begin{tabular}{|l|l|l|}
\hline Number of problems & Number of students & $\begin{array}{c}\text { Result problem posing } \\
\text { Number of }\end{array}$ \\
\hline 0 soal & 2 & 0 \\
\hline 1 soal & 2 & 2 \\
\hline s soal & 2 & 4 \\
\hline soal & 7 & 21 \\
\hline 4 soal & 19 & 76 \\
\hline SUM & 32 & 110 \\
\hline
\end{tabular}

Based on table 1 it could be seen that the majority of students were able to make the problem of four problems, but there were still students who only did less than four problems and some even did not make a problem. The total number of problem posing that had been made by 32 students as much as 110 problems. The issue would be randomized and be given back to other students to be solved. Two students did not make these problems because they were absent during the research. [3] suggested that problem posing should be too scientific learning to enhance students skills in problem-solving an independence skill better.[2] explained that the method of problem-solving learning could develop the mathematical ability which was the problem-solving ability and creative thinking ability.

TABLE II: THE STRATEGY USED IN THE PROCESS OF PROBLEM POSING BASED

\begin{tabular}{|l|l|l|}
\hline Strategy & Number of students & Percentage (\%) \\
\hline Reformulation & 4 & 3,125 \\
\hline Reconstruction & 95 & 74,219 \\
\hline Imitation & 4 & 3,125 \\
\hline No strategy & 25 & 19,531 \\
\hline Total & 128 & 100 \\
\hline
\end{tabular}

Based on table 2, it could be seen the results of the task of problem posing which do by students. Most students worked on 95 questions using reconstruction strategies. There 25 problems that did not use any strategy. It was because students did not work on the problem. In addition, it could be seen that in doing the problem given to the students there were some students who used by a combination strategy that used more than one strategy. Thus, it is concluded that the problemposing strategy presented a challenge for the students, and could improve the creativity and understanding of mathematical concepts. Based on the results of research Guvercin (2014) it mentioned that there was an increasing in the ability to understand concepts and solve mathematical problems before and after the experiment using a problemposing approach.

\section{A. Interview Analysist}

Interviews were conducted with two students who used two combination strategies of reconstruction and imitation.

"Yes ... because it gives other variations in solving the problems mathematics can be done in many ways. It's interesting to do with that. We can make our own problems and work on it" (MD, 16 years).
"It needs to a point ...... actually, it's not really hard on it. It's okay to solve it in a different way. Yesterday, when I asked to miss ririn, it may add or may reduce the problem. It is free to use in any way. It's interesting to do the same way what is taught. The most important thing is the answer is correct... "(YC 16 years).

It could be concluded that students could do math freely in accordance with their ability and understanding. They were more able to explore their ideas and creativity. Students could grab other structures for problem posing. Students could create an imitation strategy in making a problem posing. Problemposing strategies could be used well and could be used in combination with students' abilities.

\section{CONCLUSION}

Based on the results and discussion of the study, it could be concluded that the student's answer strategy in posing problem is reconstruction. Some students used the strategy because students could modify the problem-posing which made toward problems given about translation and reflection materials. Generally, students had been able to understand the material of translation and reflection because based on the problems given the students could modify by adding dots or adding translations and axes to be mirrored. However, in posing the problem students still needed a lot of guidance in order to use the imitation strategy. This was because the imitation required a better concept of understanding so that students could add to the structure of the given problem. Thus, the problem-posing learning assisted by google form could be used in the next learning and expected to make the problem posing strategies being more varied.

\section{REFERENCES}

[1] El-Sayed \& R. Abu-Elwan, "Effectiveness of problem posing strategies on prospective mathematics teachers problem solving performance", Journal of Science and Mathematics Education in S.E Asia, vol. XXV(1), 2000.

[2] A. Mahmudi, "Problem posing to evaluate the result of mathematics study", Proceeding of National Seminar and Mathematics Education, $3^{\text {th }}$ December 2011. Pendidikan Matematika FMIPA UNY, 2011.

[3] A. Purnomo, kartono, and widowati, "The models of model problem posing learning to the scientific approach to increasing problem-solving skill”, Unnes Journal of Mathematics Education Research, 2015.

[4] E. A. Silver, Mamona-Down, S. Leung, \& P.A. Kenney, "Posing mathematical problems: An exploratory study", Journal for Research in Mathematics Education, vol. 27(3), pp. 293-309, 1996.

[5] E. A. Silver \& S. Cai, "An analysis of arithmetic problem posing by middle school students", Journal for Research in Mathematics Education, vol. 27, pp. 521-539, 1996.

[6] T. Y. E. Siswono, The mathematics learning model based on problemposing for increasing creative thinking skill. Surabaya: Unesa University Press, 2008

[7] T. Y. E. Siswono, Research on Mathematics Education. Surabaya: Unesa University Press, 2010.

[8] E. Stoyanova, "Problem Posing Strategies used by years 8 and 9 Students", (Online), HTTP://www.highbeam.com/doc/IG116452511.html, 2018. 